University of Nebraska - Lincoln

DigitalCommons@University of Nebraska - Lincoln

$9-22-2019$

\title{
DISCOVERY OF THE FIRST NEARCTIC MOSS-EATING FLEA BEETLE, DISTIGMOPTERA BOREALIS BLAKE, 1943 (COLEOPTERA: CHRYSOMELIDAE: GALERUCINAE: ALTICINI)
}

Alexander S. Konstantinov

Adelita M. Linzmeier

Ana Carla Coelho Morais

Michael W. Palmer

Sonja J. Scheffer

See next page for additional authors

Follow this and additional works at: https://digitalcommons.unl.edu/usdaarsfacpub

This Article is brought to you for free and open access by the U.S. Department of Agriculture: Agricultural Research Service, Lincoln, Nebraska at DigitalCommons@University of Nebraska - Lincoln. It has been accepted for inclusion in Publications from USDA-ARS / UNL Faculty by an authorized administrator of DigitalCommons@University of Nebraska - Lincoln. 
Authors

Alexander S. Konstantinov, Adelita M. Linzmeier, Ana Carla Coelho Morais, Michael W. Palmer, Sonja J. Scheffer, and Matthew L. Lewis 


\title{
Discovery of the First Nearctic Moss-Eating Flea Beetle, Distigmoptera borealis Blake, 1943 (Coleoptera: Chrysomelidae: Galerucinae: Alticini)
}

\author{
Alexander S. Konstantinov \\ Systematic Entomology Laboratory, USDA \\ c/o Smithsonian Institution, P. O. Box 37012 \\ National Museum of Natural History \\ Washington, DC 20013-7012, USA \\ alex.konstantinov@ars.usda.gov \\ Adelita MARia LinZMeIER \\ Universidade Federal da Fronteira Sul \\ Rua Edmundo Gaievski, 1000, P. O. Box 253 \\ 85.770-000, Realeza, PR, BRAZIL \\ alinzmeier@yahoo.com.br \\ Ana Carla Coelho Morais \\ Programa de Pós-graduação em Entomologia e Conservação da Biodiversidade \\ Universidade Federal da Grande Dourados, P.O. Box 322 \\ 79.804-980, Dourados, MS, BRAZIL \\ ana_cbio@yahoo.com.br \\ Michael W. Palmer \\ Oklahoma State University \\ Department of Plant Biology, Ecology, and Evolution \\ 301 Physical Sciences, Stillwater, OK 74078-3013, USA \\ mike.palmer@okstate.edu \\ Sonja J. Scheffer and Matthew L. Lewis \\ Systematic Entomology Laboratory, USDA \\ c/o Smithsonian Institution, P. O. Box 37012 \\ National Museum of Natural History \\ Washington, DC 20013-7012, USA \\ sonja.scheffer@ars.usda.gov, matthew.lewis@ars.usda.gov
}

\begin{abstract}
A flea beetle, Distigmoptera borealis Blake, 1943, is documented for the first time to feed on liverworts, Reboulia hemisphaerica (L.) Raddi (Aytoniaceae), and moss, Weissia controversa Hedw. (Pottiaceae). This is the first and only known bryobiont leaf beetle in the USA and Nearctic biogeographic region. The adult of $D$. borealis is redescribed and illustrated, and the larva and pupa of $D$. borealis are described and illustrated for the first time.
\end{abstract}

Key Words: leaf beetle, bryobiont, moss, liverwort, USA, morphology

DOI.org/10.1649/0010-065X-73.3.599

Flea beetles that inhabit moss cushions constitute a relatively recently discovered ecological group within the otherwise hyperdiverse family of leaf beetles (Coleoptera: Chrysomelidae). Most adult leaf beetles live on leaf surfaces of their host plants. So far, out of 9,900 flea beetle species (Coleoptera: Chrysomelidae: Galerucinae: Alticini) assigned to 577 genera (Konstantinov 2016), 44 species from 17 genera have been collected in moss cushions
(Konstantinov et al. 2013; Takizawa and Konstantinov 2018). Only seven species of flea beetles from three genera are documented to actually eat mosses (Cox 1997; Nadein 2009; Konstantinov et al. 2013; Damaška and Aston 2019).

Flea beetle collecting in moss cushions in Asia (Bhutan, China, India, Japan, Nepal, Thailand), Central America (Nicaragua, Panama), South America (Bolivia, Brazil) and the West Indies 
(Dominican Republic, Jamaica, Puerto Rico, St. Lucia) suggests that moss-associated species occur in mostly tropical environments, in wet forests at various (but almost always locally significant) altitudes (Konstantinov and Chamorro-Lacayo 2006; Konstantinov et al. 2009, 2013, 2014, 2015; Damaška and Konstantinov 2016). Studies of moss cushions along latitudinally oriented mountain ridges in Western Yunnan (China) in 2002, 2011, and 2012 supported this idea. During these studies, we found numerous flea beetles along Cangshan and Baoshan mountain ridges around $24-25^{\circ}$ latitude; however, about $140 \mathrm{~km}$ north along the same ridges, at $27^{\circ} 12^{\prime}$ and $27^{\circ} 49^{\prime}$, flea beetles were absent from moss cushions (Konstantinov et al. 2013). Substantial efforts in 2002 and 2016 to find mossinhabiting flea beetles in North America in the high elevation, moss-covered mountain forest of the Appalachians failed to reveal flea beetles.

Based on these observations, we suspected that (except for Mniophila muscorum Koch, known from England and other places in Europe) mossinhabiting flea beetles were mostly absent from temperate low- and highland forests in the Old and New Worlds. However, the discovery by M. W. Palmer of a moss-eating and inhabiting flea beetle, Distigmoptera borealis Blake, 1943 (Fig. 1), in lowland Oklahoma proved otherwise.

\section{Material and Methods}

Collecting Localities. Locality 1: USA: Oklahoma, Payne County, $10 \mathrm{~km} \mathrm{~S}$ of Stillwater, env. of Mehan, $36.014609^{\circ} \mathrm{N} 96.995457^{\circ} \mathrm{W}, 20$. III.2016, elev. $280 \mathrm{~m}$ Leg. Mike Palmer. Locality 2: USA: Oklahoma, Payne County, $5 \mathrm{~km}$ W of Stillwater, McPherson Preserve $36.101371^{\circ} \mathrm{N} 97.205279^{\circ} \mathrm{W}$, 21.III.2016, elev. 311 m, Leg. Mike Palmer. Both sites are sunny (but north-facing) rocky roadsides (Fig. 32) that are infrequently mowed by country road crews. The rock is sandstone.

Adult specimens of Distigmoptera Blake were found in bryophyte samples collected in the field and brought into the laboratory, but the beetles were never encountered in the field directly. Bryophyte samples were maintained moist, by a north-facing window, and at room temperature. Suspected predatory arthropods were removed from containers when encountered. Vascular plant seedlings were removed shortly after germination. Larvae were encountered at first on the surface of moss samples. They were also feeding below the surface. Sometime later, adults of Distigmoptera appeared in the same containers. No other beetles, except staphylinids with dramatically different larvae, were present in the samples.

To determine whether the bryophyte-feeding larvae were conspecific with the adult $D$. borealis, we

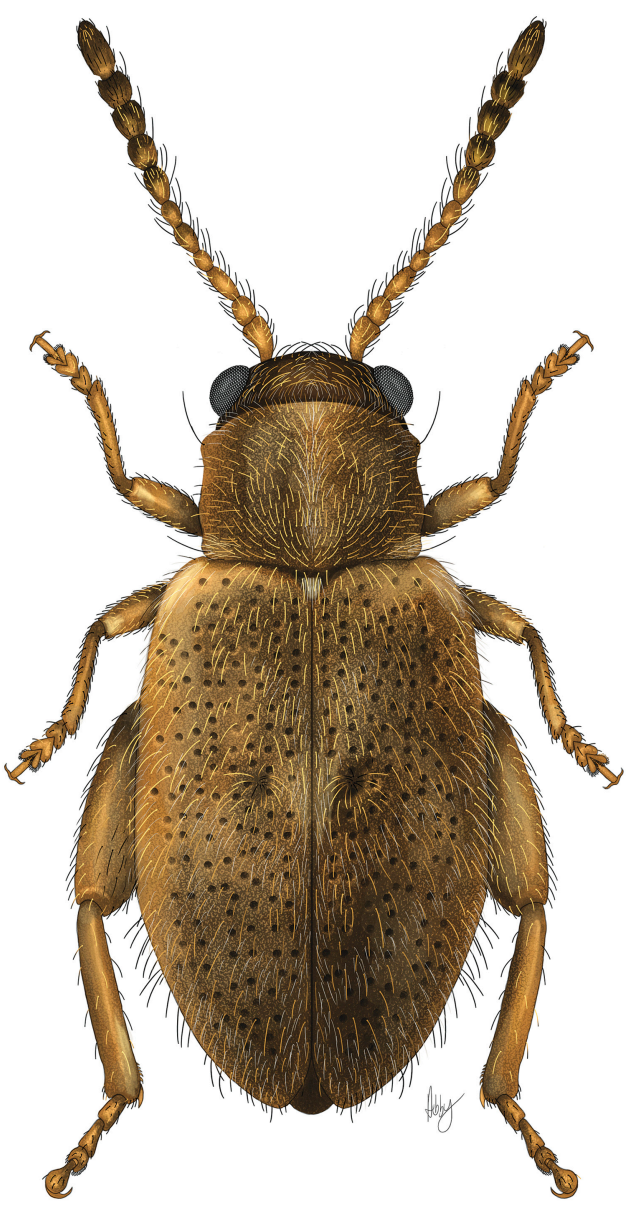

Fig. 1. Distigmoptera borealis, dorsal habitus.

sequenced mitochondrial cytochrome barcode region of one larval and one adult specimen. DNA was extracted using the DNeasy Blood and Tissue Kit (Qiagen, Valencia, CA, USA). PCR amplification of the DNA barcode region of cytochrome oxidase subunit I (COI) was performed using primers LCO and HCO (Folmer et al. 1994). PCRs were performed on a Tetrad 2 thermocycler (BioRad, Hercules, CA, USA) with the following "touchdown" program: initial denaturation for two minutes at $92^{\circ} \mathrm{C}, 12$ touchdown cycles from $58^{\circ} \mathrm{C}$ to $46^{\circ} \mathrm{C}\left(10\right.$ seconds at $92^{\circ} \mathrm{C}, 10$ seconds at $58-46^{\circ} \mathrm{C}$, one minute at $72^{\circ} \mathrm{C}$ ), 27 cycles at 10 seconds at $92^{\circ} \mathrm{C}, 10$ seconds at $45^{\circ} \mathrm{C}$, one minute at $72^{\circ} \mathrm{C}$, and a final extension for seven minutes at $72^{\circ} \mathrm{C}$. PCR products were enzymatically purified for sequencing by using ExoSAP-IT (Affymetrix, Santa Clara, CA, USA). Sequences were generated with the amplifying primers by using the BigDye Terminator v3.1 Sequencing kit (Applied 
Biosystems, Foster City, CA) and fractionated on an ABI 3730XL Genetic Analyzer. Sequences were edited in Geneious R10 (Biomatters, New Zealand). Sequences from the larval and adult specimens were identical.

Dissecting techniques and adult morphological terminology follow Konstantinov (1998). In addition, terminology for adult thoracic structures and ridges follows Lawrence and Ślipiński (2013), Lingafelter and Konstantinov (2000), and McHugh et al. (1997). Larval terminology mostly follows LeSage and Zmudzinska-Krzesinska (2004). Specimen observations were made with a Zeiss Stemi SV11 Apo microscope. Digital photographs were taken with an Axio Zoom V16 microscope equipped with an AxioCam HRC digital camera and with an AxioCam HRC Zeiss attached to a Leitz Diaplan compound microscope. The specimens are deposited in collections of the National Museum of Natural History, Smithsonian Institution, Washington DC, USA (USNM). For listing label data of examined specimens, we use the convention implemented in Konstantinov et al. (2011).

\section{RESULTS}

Altogether, 16 species of Distigmoptera are known, including one in Canada, two in Costa Rica, three in Mexico, and one in the Dominican Republic and Puerto Rico. Nine Distigmoptera species occur in the USA (Riley et al. 2003). Information on plant associations for Distigmoptera exists for only three North American species: D. apicalis Blake, D. borealis Blake and D. pilosa (Illiger) (Clark et al. 2004). However, until now, there were no documented observations of Distigmoptera adults or larvae feeding. Hence, Clark et al. (2004) in their treatment of host plants of North American leaf beetles admitted that "it is unknown which, if any, of these plants are hosts." Thus, this report is the first to provide firm evidence for a food plant association of Distigmoptera.

\section{Distigmoptera borealis Blake, 1943}

(Figs. 1-31, 35)

Distigmoptera borealis Blake 1943: 217 (Holotype, male, type locality "Swift Current, Saskatchewan," USNM).

Description of Adult. Body 2.27-2.97 mm long, 1.24-1.45 mm wide, pubescent, elongate, moderately flat in lateral view. Dorsum from light yellowish/straw color to dark brown to blackish. Setae from white to yellow to black. Pronotum and head often darker; humeral callus lighter than rest of elytron. Elytron with 2 dark spots, 1 near middle adjacent to suture, within semicircular impression, another in apical third. Dark spots only visible when elytron light in color (Figs. 2, 3).
Head (Fig. 4) slightly convex in lateral view, evenly and strongly punctured and pubescent. Frons and vertex forming slightly convex line in lateral view. Supraorbital pore indistinguishable. Antennal callus visible, nearly quadrate; surface situated at same level as vertex. Midfrontal sulcus wide and deep. Supracallinal and supraorbital sulci absent, often substituted with punctures. Suprafrontal and supraantennal sulci shallow. Orbital sulcus absent. Orbit as wide as antennal callus. Interantennal space about as wide as transverse diameter of eye. Antennal socket rounded. Frontal ridge wide, parallel-sided. Anterofrontal ridge low, slanted dorsally, merged with frons. Eyes small, slightly protruding laterally; inner margin slightly curved. Labrum deeply notched in middle, with 6-8 setiferous pores, some placed symmetrically, others not. Antenna with 11 antennomeres; antennomere 7 widening abruptly compared to antennomere 6 (Fig. 2).

Pronotum 1.43 times wider than long (Fig. 5). Pronotal disc medially raised in 2 low ridges separated by shallow impression. Lateral sides of pronotum close to lateral margins, with 2 low and dull ridges. Anterior margin straight, with distinct border. Lateral margins subparallel, very slightly convex, without explanation. Lateral sides slightly convex in middle. Posterior margin nearly straight, without distinct border. Anterolateral callosity globular and evenly rounded, bearing seta, not forming denticle posteriorly (Fig. 6). Posterolateral callosity small, bearing long seta. Pronotal surface covered with large, closely placed punctures and with yellow (posterior corners), whitish, and black setae. Scutellum triangular, roundish at apex, densely covered with whitish setae. Prosternal surface densely covered with irregular punctures. Prosternal intercoxal process extended posteriorly beyond coxa, truncate posteriorly; posterior end about twice as wide as middle. Procoxal cavities closed posteriorly.

Mesotergite with longitudinal mesothoracic ridge short (Fig. 10). Mesanepisternum (Fig. 12) as broad and long as mesepimeron. Mesosternum short. Mesocoxal cavity transversely ovoid. Mesoventral process concave at apex, longer than metaventral process (Fig. 12). Metathoracic discrimen short. Metanotum with ridge $D$ gently curved inwards and ridges $C 3$ and $D$ merging gradually (Fig. 11). Ridge $C 3$ about as long as $C 1$, about twice length of $C 2$. Oblique suture of metascutum poorly visible. Metascutellar groove nearly parallel-sided. Metendosternite (Fig. 13) with thin stalk and arms about three times as wide as stalk at apex.

Elytral surface punctate (Fig. 9), with punctures forming 9 striae (not counting marginal and short scutellar striae), densely pilose with black, yellow, and white setae. Interspaces generally flat. Humeral 

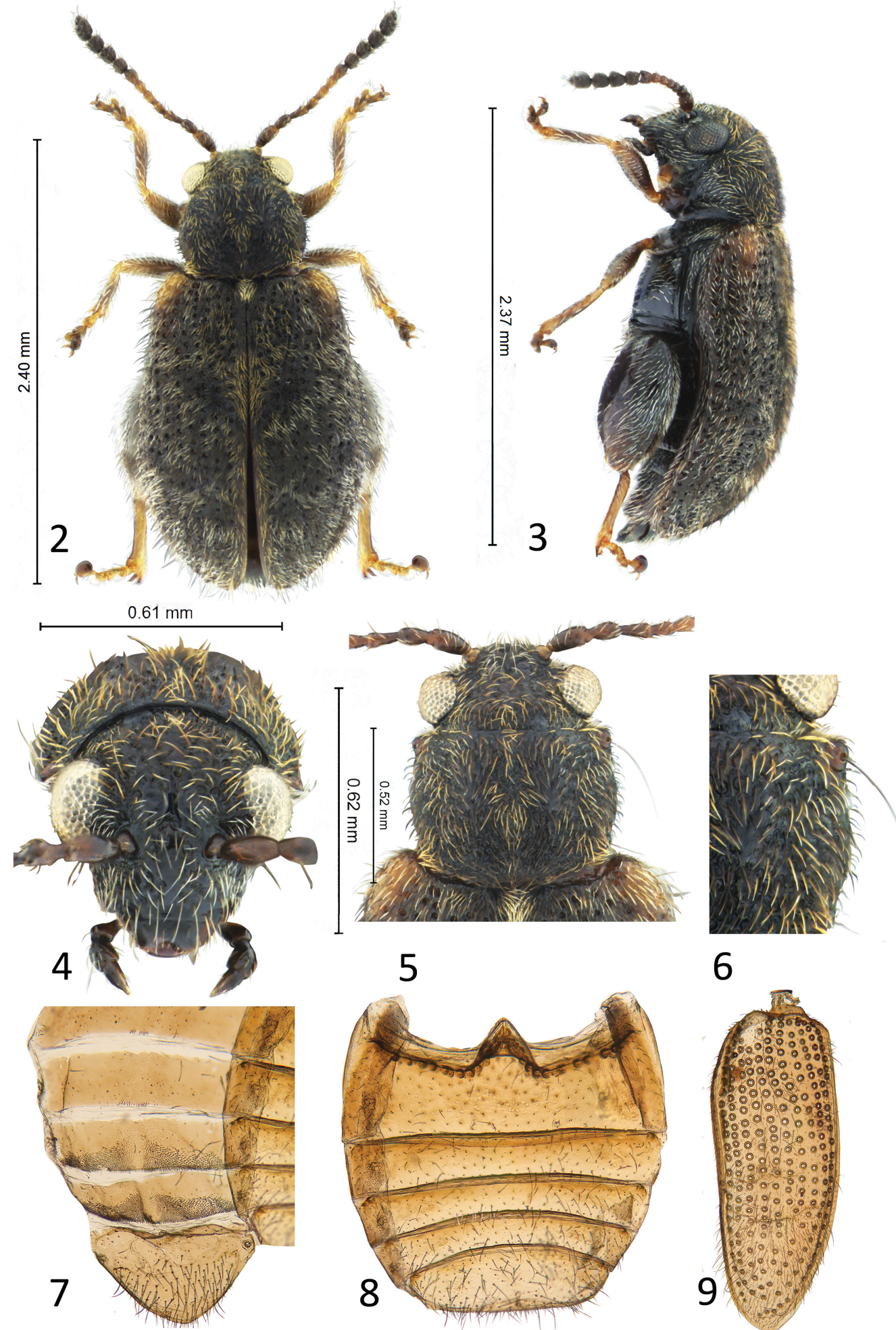

6
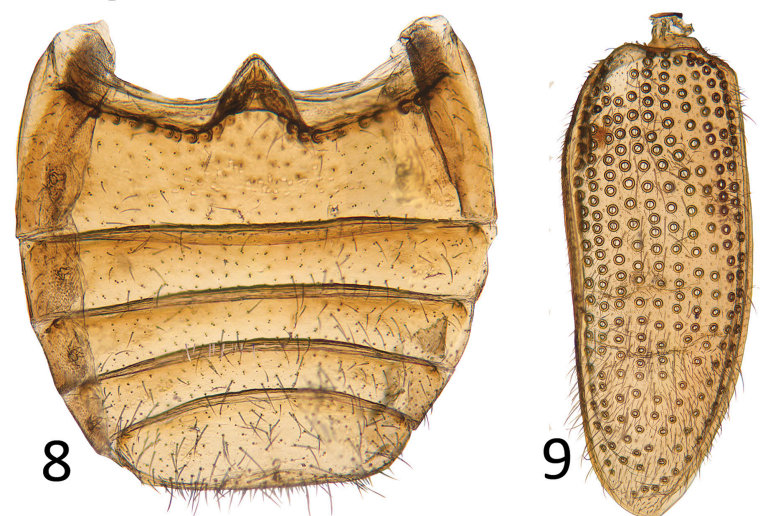

Figs. 2-9. Distigmoptera borealis. 2) Dorsal habitus; 3) Lateral habitus; 4) Head, frontal view; 5) Head and pronotum; 6) Pronotum, right anterolateral corner; 7-8) Female abdomen, dorsal and ventral views, respectively; 9) Left elytron. 


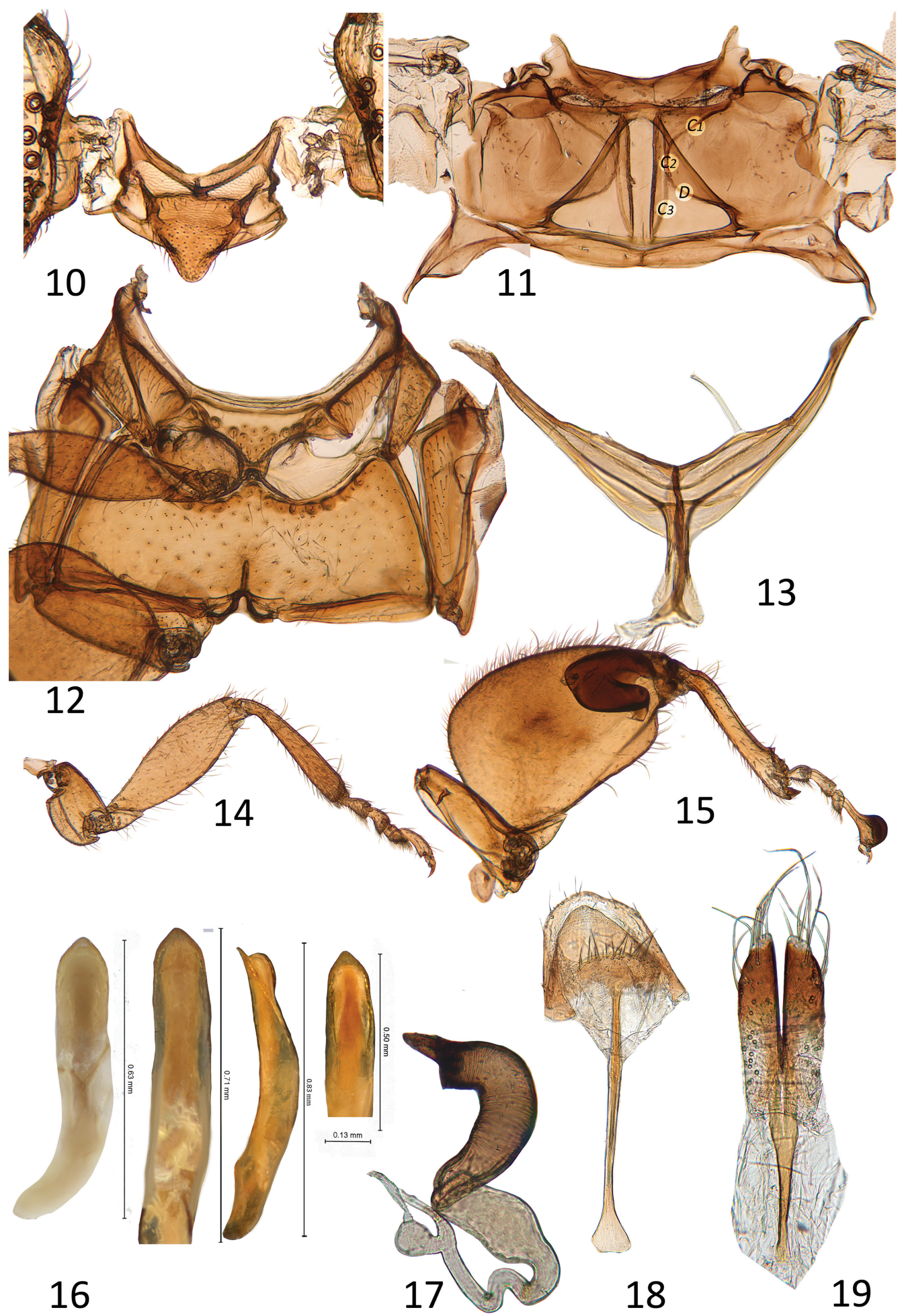

Figs. 10-19. Distigmoptera borealis. 10) Mesotergite; 11) Metatergite, $C 1-C 3$ and $D$ ridge numbers according to Konstantinov (1998); 12) Meso- and metasternites; 13) Metendosternite; 14) Middle leg; 15) Hind leg; 16) Median lobe of aedeagus, dorsal, ventral, lateral, and dorsal views, respectively; 17) Spermatheca; 18) Tignum; 19) Vaginal palpi. 
callus present. Base of elytron with callus situated between suture and humeral corner. Elytron with shallow pits slightly above middle along punctural rows 2 and 4. Epipleura nearly vertical, parallelsided until narrowing abruptly near elytral apex, not reaching apex. Elytral apex gently curved, acute.

Pro- and mesofemora slightly dilated. Pro- and mesotibiae subcylindrical, somewhat enlarged below middle, narrowing towards apical edge (Figs. 2, 3, 14), lacking apical spurs; long, curved setae present in addition to short setae. Metafemur greatly enlarged (Fig. 15). Metatibia slightly curved in lateral and dorsal views. Outer and inner dorsal ridges more or less straight, with lateral ridge sharper than median. Transverse ridge forming denticle, connecting dorsal ridges near tarsal insertion. Metatibial apex with sharp denticle laterally adjacent to metatibial spur. Metatibial spur welldeveloped. First metatarsomere inserted preapically, about as long as subsequent tarsomere. Claw tarsomere swollen (Fig. 15). Claw appendiculate in female.

Abdomen pubescent, with 5 visible sternites. Apical sternite shorter than 3 preceding sternites combined, without appendages basally (Fig. 8). Basal sternite shorter than 3 following sternites together. Last abdominal tergite of female without groove in middle, evenly covered with long setae (Fig. 7).

Median lobe of aedeagus simple, slightly curved in lateral view, with lateral margins almost parallel in ventral view; apex subtriangular, without denticle (Fig. 16). Ventral side flatter apically than basally.

In female genitalia, posterior part of sternite VIII sclerotized along entire margin (Fig. 18). Tignum with rounded anterior margin, evenly sclerotized, bearing many moderately long setae (Fig. 18). Vaginal palpi elongate (Fig. 19), strongly sclerotized anteriorly and along middle, merged anteriorly for more than half their length, each with about 8 apical setae, with posterior sclerotization about as long as anterior sclerotization. Spermatheca curved (Fig. 17), with receptacle and pump not differentiated from each other (pump about as wide as receptacle). Apex of pump with flattened projection. Spermathecal duct as wide as receptacle at base, long, forming " $\mathrm{S}$ " coils.

Variation. The color of beetles varies greatly among specimens preserved as long ago as 1882 and those collected most recently. The older specimens are pale to almost straw-colored with uniformly light setae and the head, pronotum and often legs being a bit darker (Fig. 1). The newly collected specimens (Figs. 2, 3) have a darker (almost black) body surface, and the setae are white to dark yellow to black. This variability may also be a result of different preservation techniques, as well as geographic variation.
Diagnosis of Larva. Head well-sclerotized, slightly inserted in pronotum; body covered with several sclerites, arranged in two transverse rows on mes- and metathoraces and abdomen fused in single dorsal sclerite on pronotum. Integument with granulate microsculpture (grains ovoid) between sclerites. Hollowed, spatulate setae on dorsal sclerites; filiform setae on venter. Frons with pair of short digitiform setae close to endocarina. Stemmata absent. Antennae short. Presence of circular hollow on abdominal segments I-VII among dorsolateral sclerites. Legs slightly sclerotized; prothoracic legs smaller than following legs; pulvillus bladder-like.

Description of Larva. (Figs. 20-30). Larva eruciform (Fig. 35), slightly curved when preserved in ethanol. Head and pronotum somewhat narrower than following segments. Length $=3 \mathrm{~mm}$; width = $0.8 \mathrm{~mm}$.

Integument pale yellow, with brownish microsculpture dorsally; thorax and abdomen with brownish dorsal and lateral sclerites; dorsolateral abdominal tubercles dark yellow to brown; ventral region almost white. Head dark brown. Legs slightly sclerotized, dark.

Head hypognathous (Figs. 20, 21, 24, 25), wellsclerotized, rounded anteriorly, forming short posterior projection on each epicranial plate (in dorsal view), slightly inserted into prothorax. Epicranial suture distinctly Y-shaped. Coronal suture short (1/5 length of head). Frontal sutures pale, broadly diverging from base, arched, reaching antennal sockets. Endocarina forming black line running from junction of coronal and frontal sutures to transverse frontoclypeal suture, altogether forming black T-shaped structure. Each epicranial plate with 2 spatulate setae along frontal suture, 1 on basal third, 1 almost medially; 4 microsetae arranged in oblique, irregular row from posterior region to frontal suture; 4 filiform setae present, 2 on anterior region (1 ventrally), 1 between spatulate setae and 1 on medial region of anterior third; 3 sensilla, 1 situated on posterior region close to microsetae, 1 medially close to frontal suture and 1 anteromedially on outer region. Stemmata absent. Frons with pair of long spatulate setae and pair of sensilla, 1 on each side of endocarina; 1 pair of short digitiform setae close to endocarina; 2 pairs of filiform setae present, both almost on frontoclypeal suture. Base of antennae with 3 filiform setae. Clypeus transverse, concave medially, lateral margins rounded, bearing pair of short filiform setae on each side. Labrum (Fig. 28) transverse, darker and narrower than clypeus, anterior margin concave, nterior angles rounded, bearing a filiform seta on each side and 2 filiform setae medially.

Antenna reduced, articulation area prominent, strongly convex, membranous, situated at ends of fontal suture, slightly sclerotized at base; 


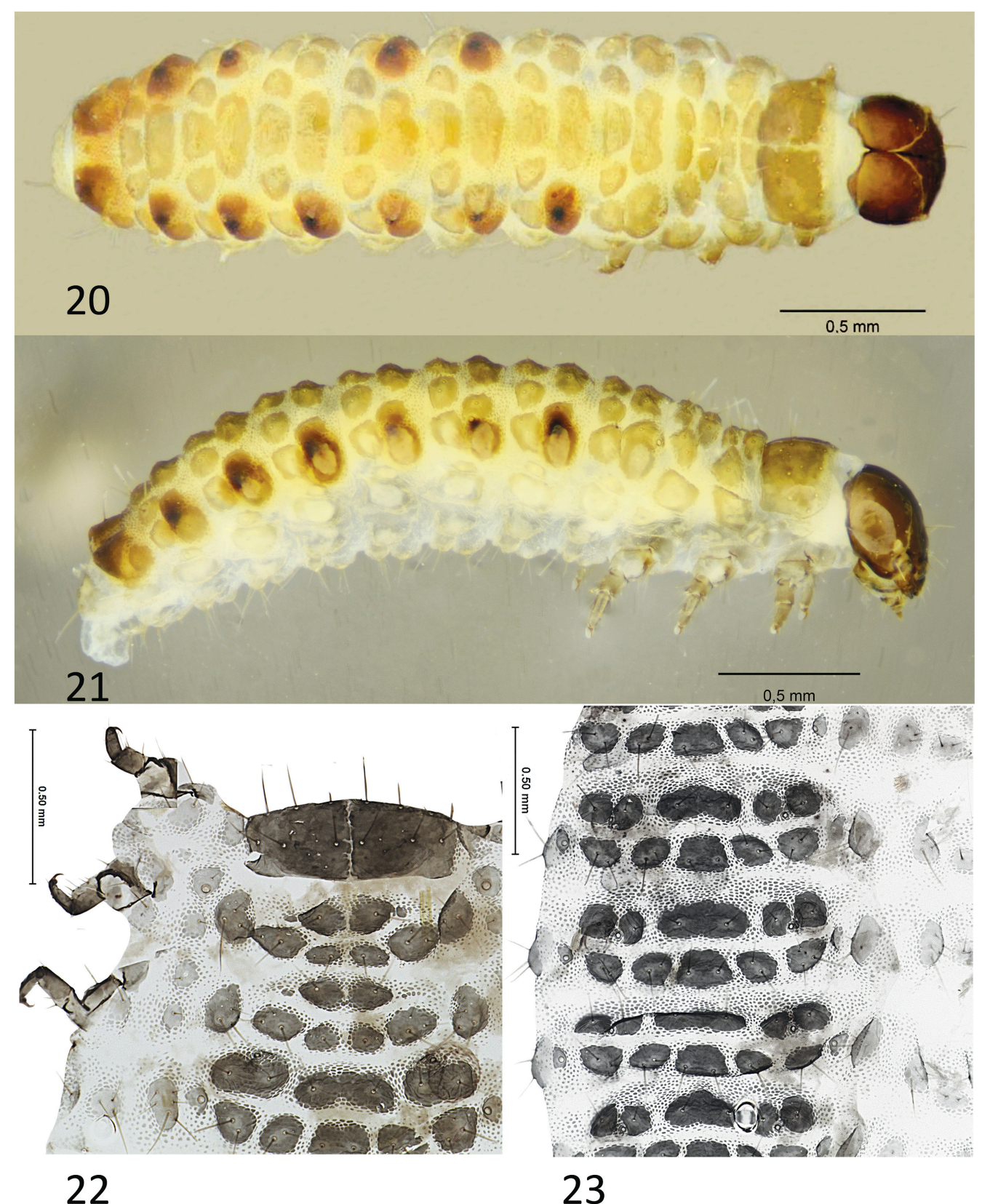

Figs. 20-23. Distigmoptera borealis, larva. 20) Dorsal habitus; 21) Lateral habitus; 22) Thoracic segments; 23) Abdominal segments.

3-segmented, antennomere 1 partly membranous, antennomere 2 narrow, slightly sclerotized, bearing 4 sensilla, antennomere 3 conical. Mandibles symmetrical (Fig. 26), palmate; 4-toothed, inner tooth small, slightly rounded, other teeth robust, black, heavily sclerotized, penultimate tooth longer than others. Penicillus formed by 4 digitiform penicillar setae. Two mandibular setae present on outer mandibular base. Maxilla elongate, slightly wider posteriorly; cardo short, subtriangular, bearing 1 posterior filiform seta. Stipes and palpiger bearing pair of filiform setae. Maxillary palpi with 3 

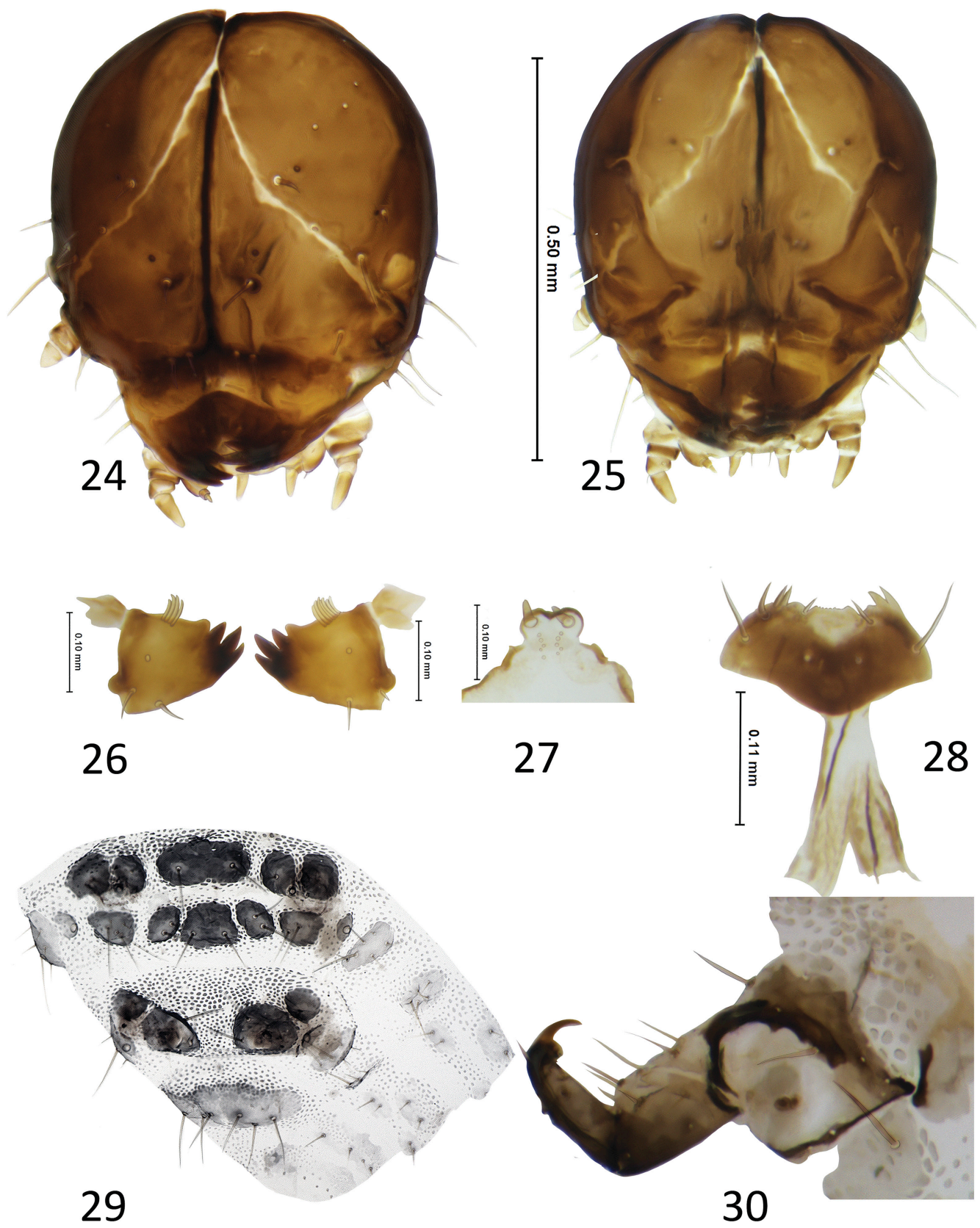

Figs. 24-30. Distigmoptera borealis, larva. 24) Head, $3 / 4$ view; 25) Head, frontal view; 26) Mandibles; 27) Labium; 28) Labrum; 29) Apical abdominal segments; 30) Leg.

palpomeres; basal and $2^{\text {nd }}$ palpomeres bearing pair of filiform setae, 1 anterolateral and 1 medial; distal palpomere conical, longer than 2 preceding palpomeres combined, bearing sensillum medially. Palpiger bearing 2 filiform setae ventrally. Galea not distinctly separated from lacinia, both represented by 2 palpus-like projections formed by 2 palpomeres, surrounded by many thick, spiniform setae. Labium as long as maxilla, formed by single sclerite, bearing pair of long setae medially, 2 pairs of microsetae close to medial filiform setae, 1 pair of short setae posteriorly and 1 pair of short setae at 

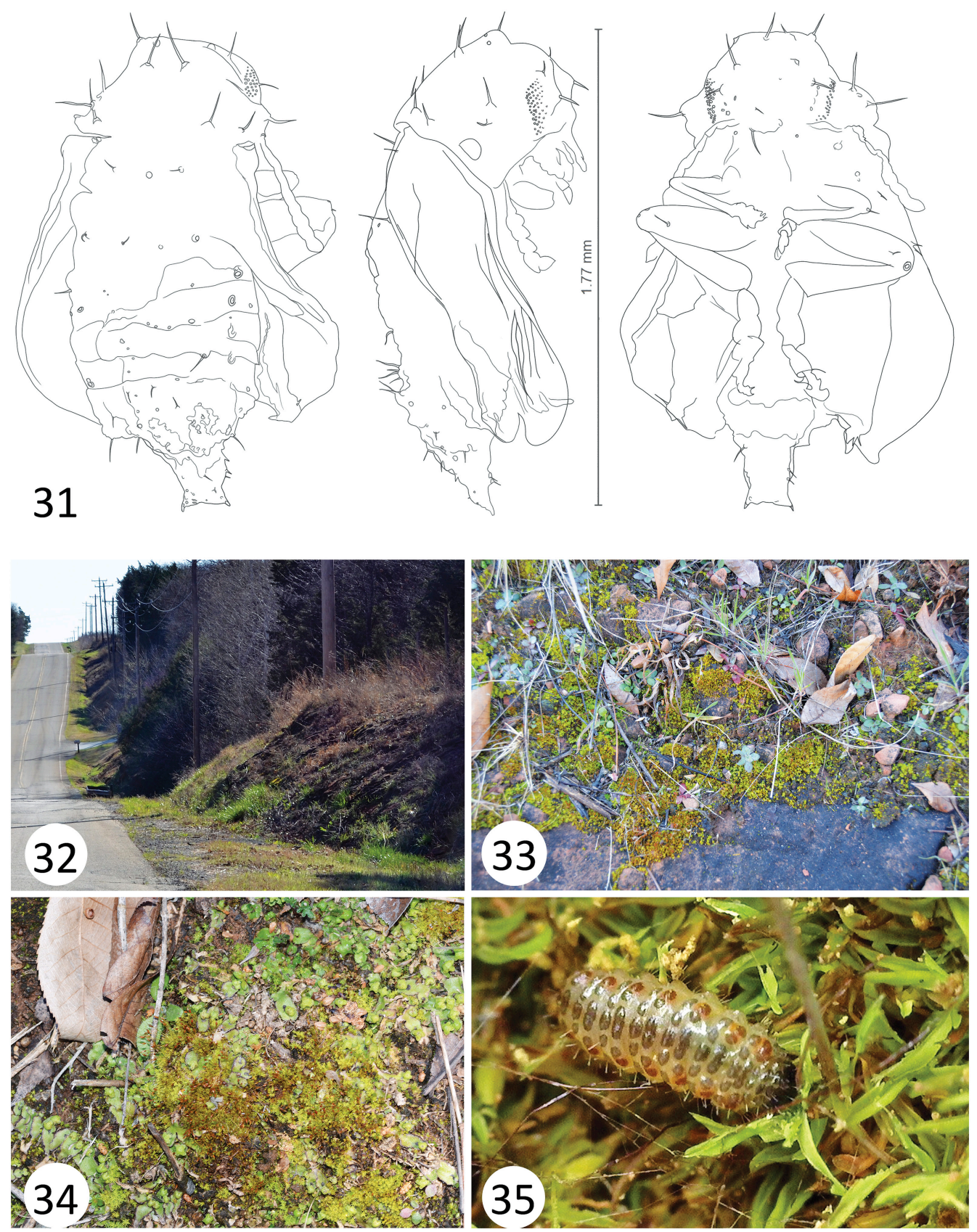

Figs. 31-35. Distigmoptera borealis. 31) Pupa, dorsal, lateral, and ventral views, respectively; 32) Larval habitat; 33) Mostly Weissia with assorted vascular plants; 34) Mostly Reboulia (flat green), Weissia, other assorted bryophytes, and Nostoc sp. (Nostocaceae; dark, black, never observed in culture, so it could not be determined if there was any flea beetle feeding on it); 35) Larva feeding on Weissia controversa.

base of palpi. Labial palpi with 2 palpomeres, apical palpomere elongate, conical, bearing sensillum.

Prothorax narrower and darker than following thoracic segments (Figs. 20, 21, 22). Pronotum transverse, subrectangular, anterior margin wider than posterior margin, lateral margins slightly rounded, anterior angles rounded; dorsal sclerite well-developed, divided by lighter ecdysial line 
medially, bearing 7 large, hollowed, spatulate setae and 3 microsetae (on each half), arranged as follows: 3 large, hollowed, spatulate setae on anterior margin, 2 on lateral margin (1 at anterolateral corner) and 2 medially, with 3 microsetae in between. Anterolateral sclerite of prothorax small, subquadrate, close to dorsal sclerite, bearing 2 filiform setae.

Meso- and metathoraces narrower and slightly wider than prothorax (Figs. 20, 21, 22). Mesonotum with 4 dorsal, 2 dorsolateral ( 1 on each side), and 6 lateral sclerites (3 on each side), laterocentral sclerite larger than others. One large, hollowed, spatulate seta on each dorsal sclerite; 3 large, hollowed, spatulate setae on each dorsolateral sclerite; 1 filiform seta on each anterolateral and posterolateral sclerite and 3 large, hollowed, spatulate setae on centrolateral sclerite. Mesothoracic spiracle annuliform, relatively large, emerging from anterolateral mesothoracic sclerite. Metathorax similar to mesothorax, without spiracle. Pro-, meso- and metasterna with medial tubercle, each bearing 1 pair of filiform setae, integument microsculptured.

Legs slightly sclerotized, 5-segmented, similar in form (Figs. 21, 22, 30). Prothoracic legs smaller than meso- and metathoracic legs. Procoxae narrow, with 2 dorsal sclerites (anterior sclerite slightly darker), each sclerite bearing 1 filiform seta, anterior sclerite also with 2 microsetae. Meso- and metacoxae each bearing 1 filiform seta and 3 microsetae. Trochanters each broadly trapezoidal, membranous, with lateral margins slightly sclerotized; protrochanter bearing 4 filiform setae, 2 of them shorter, and 3 microsetae; meso- and metatrochanters each bearing 3 filiform setae, 1 of them shorter, and 3 microsetae. Femur slightly sclerotized, bearing 8 filiform setae, 4 of them short. Tibia slightly sclerotized, slightly longer than femur, enlarged at base, decreasing in size towards apex, bearing 8 filiform setae ( 5 dorsal and 3 ventral). Tarsungulus sclerotized, moderately curved; pulvillus bladderlike, as long as tarsungulus.

Abdominal segments I-VII with 14 sclerites forming small tubercles (Figs. 20, 21, 23, 29); 4 dorsal sclerites present (1 anterior, subrectangular, and wide, 3 posterior, central sclerite subquadrate and larger than lateral sclerites), each bearing 2 hollowed, spatulate setae; 6 rounded dorsolateral sclerites ( 3 on each side) bearing 2 filiform setae each, with 2 anterior sclerites darker than $2^{\text {nd }}$ segment; 4 lateral sclerites ( 2 on each side), smaller sclerite bearing spiracle, larger sclerites bearing 6 filiform setae each. Segment VIII narrower than previous segments, dorsal sclerite covering almost all dorsal portion, darker posterolaterally, bearing 3 filiform setae on each part; 2 ventrolateral sclerites ( 1 on each side) bearing 6 filiform setae. Circular hollow (maybe a glandular opening) present on segments I-VII between dorsolateral sclerites. Segment IX dorsally forming individual semicircular pygidium with 6 filiform, long setae. Segment $\mathrm{X}$ not visible in dorsal view, bearing pygopod. Spiracles present on segments I-VIII, similar to mesothoracic spiracles but smaller, between dorsolateral and lateral sclerites. Segments I-VIII each with 2 ventrolateral tubercles, outer tubercle larger and bearing 6 filiform setae (posterior seta longer), inner tubercle bearing 5 filiform setae (posterior seta longer). Venter of segments I-VIII with grooves delimiting anterior and posterior areas; anterior area bearing 2 filiform setae, posterior area bearing pair of filiform setae on each lateral margin. Segment IX with ventral region similar to dorsal region in form and chaetotaxy.

Larval Variation. We observed variation in the number of large, hollowed, spatulate setae on the pronotum. A single specimen (not illustrated here) has eight large, hollowed, spatulate setae arranged as follows: three on the anterior margin, two on the lateral margin, one almost medially and two close to the posterior margin. The specimen illustrated in Fig. 22 has only one seta close to the posterior margin, so there are seven large, hollowed, spatulate setae on each side of the pronotum.

Description of Pupa. Body $1.7 \mathrm{~mm}$ long, slightly bent in lateral view, cream in color, bearing long, brownish setae inserted in small tubercles. Head invisible from above, bearing long and short setae. Prothorax bearing 4 pairs of dorsal setae and pair of setae on lateral callosities; meso- and metanota bearing 2 pairs of setae each; each femur bearing a pair of setae near apex. Abdominal segments I-VI bearing dorsal setae; segment IX with 2 distal projections, each bearing a stout seta on apex (Fig. 31).

Host plants. Larvae and adults were observed consuming the liverwort Reboulia hemisphaerica (L.) Raddi (Aytoniaceae) (Fig. 34) and gametophytes of the moss Weissia controversa Hedw. (Pottiaceae) (Fig. 33). Adults were also observed eating capsules (sporophytes) of Weissia sp.

Faunal Associates. Moss samples containing $D$. borealis were also inhabited by mites, collembolans, spiders, staphylinid beetles, flies (tipulids, sciarids, and ceratopogonids), wasps (chalcidoids and braconids, not clearly associated with particular host species), and moths (Scoparia sp., Bryotropha sp., and Microcrambus elegans (Clemens)).

Other Biological Observations. Larvae were encountered from mid-January to mid-May. Adults were encountered from mid-March to June (moss typically desiccated in the field in summer through autumn, and adults were then not found even after soaking rains). Inactive larvae may be found curled up in the soil under moss clumps in a small chamber. Larvae near pupation readily succumb to white 
mold in culture. Larvae move slowly and will curl into a C-shape when disturbed. Adults also move slowly but are capable of jumping when disturbed (though they do not always do so). Mating or egglaying was not observed. No parasitoids were unambiguously associated with $D$. borealis.

Comments. Distigmoptera borealis larvae are free-living, inhabiting moss cushions and eating bryophytes and marchantiophytes (Fig. 35). Morphologically, they are similar to free-living larvae of Pseudolampsis Horn, Altica Geoffroy, and Ivalia Jacoby, owing to the eruciform habitus, short coronal suture with the frontal sutures diverging and reaching the antennal sockets, sclerotization of the tubercles, absence of highly elongate tubercles, and presence of a specialized granular integument between the tubercles (Casari and Duckett 1997; LeSage and Zmudzinska-Krzesinska 2004; Duckett et al. 2006). Among these genera, only Pseudolampsis and Distigmoptera belong to the subtribe Monoplatini. Larvae of these two genera share the presence of dorsolateral openings on abdominal segments I-VIII, probably associated with some glandular secretion. However, $D$. borealis differs from Pseudolampsis in that the mandibles are four-toothed with four digitiform penicillar setae (five-toothed mandibles with penicillus formed by ramified setae in Pseudolampsis), the cardo has one posterior filiform seta (seta absent on cardo in Pseudolampsis), and the head lacks stemmata (one pigmented stemma on each side in Pseudolampsis).

In addition to the similarity mentioned above, larvae of D. borealis, Altica, and Ivalia also share the absence of stemmata, the shape of the endocarina, and the number of large setae on the pronotum (LeSage and Zmudzinska-Krzesinska 2004; Duckett et al. 2006). However, these larvae differ in the presence of glandular openings in $D$. borealis (absent in Altica and Ivalia) and in the form of their large setae: $D$. borealis has hollowed, spatulate setae in the dorsal, dorsolateral, and lateral regions; Altica has capitate and hollowed, capitate setae on the dorsum, lateral areas, pronotum, legs, and postcephalic sclerites; the setae in Ivalia are all capitate and located dorsally on the abdomen.

Other described larvae of Alticini, such as Walterianella bucki Bechyné, 1956 (Duckett 2002) and Alagoasa januaria Bechyné, 1955 (Duckett and Swigoňová 2002), both external leaf-feeding species belonging to the subtribe Oedionychina, are very distinct, mainly due to the presence of prominent tubercles on the body.

Material Examined. Holotype, male, 1) Swift Current, Brit. Amer. Sept. 1882 (C. V. Riley collection); 2) Distigmoptera borealis Blake; 3) Type No 56748 USNM (USNM). Paratypes: same labels as holotype (8 USNM).
CANADA: ALBERTA 1) Edmonton. Alta. 4.X.1917 F. S. Carr; 2) male; 3) Hypolampsis pilosa (Ill.) det. by 19. L. G. Gentner; 4) Distigmoptera borealis Blake (1 male USNM). ONTARIO 1) Rondeau Pk. ONT, 1-5.IX.1985 L. LeSage \& A. Woodliffe; 2) Distigmoptera borealis Blake Det. L. LeSage (1 USNM). QUÉBEC 1) Duparquet Que., 1.IX.1936 G. Stace Smith; 2) On rain pond; 3) 15861. (1 USNM). The same label except 31.VIII.1936 (1 USNM). USA: COLORADO 1) Col. Nunn Pawnee Grassland Pasture, Owl Creek, 23.XI.1971; 2) Distigmoptera borealis Blake det. R. White, 1972 (1 USNM). IOWA 1) Iowa City In, IX.3.17 L. Buchanan (9 USNM). INDIANA 1) So. McAlester Ind. T. June 11, Wickham; 2) Wickham Collection 1933 (1 USNM). KANSAS 1) Russel Co, Kansas (1 USNM). 1) Topeka Ks, Popenoe (1 USNM). 1) Reno Co. Ks, IX.15.41; 2) R. Schwitzgebel Coll; 3) 16; 4) H.S. Barber (1 USNM). MICHIGAN 1) Higgins Lake, Mich. 29 July 1923 L.G. Gentner; 2) L.G. Gentner Collection (20 USNM). Some with label "Hypolampsis pilosa L.G.G Ill”. 1) Marquette1.8. Mich.; 2) Coll Hubbard \& Schwarz (7 USNM). MONTANA 1) Wyo, Colstrip, MT TER/ Q31, Qick trap2, VII.5.197; 2) J. Leetham Collector; 3) CHRY D180; 4) M55 (1 USNM). 1) Colstrip, MT., TER/Q31, soil core VI.29.1974 AGSH; 2) J. Leetham Collector; 3) MALA 02; 4) M97 (1 USNM). NEW YORK 1) Ithaca N.Y., 4 July 04 (1 USNM). NORTH DAKOTA 1) North Dakota: Mercer CO., T144N, R84W, S22, July 5-7, 1972, A.C.F. Hung (1 USNM).

\section{ACKNOWLedGMents}

We are grateful to Abby Williams, who, during her scientific illustration internship at National Museum of Natural History in June 2016, prepared the habitus illustration of $D$. borealis (Fig. 1). We are also grateful to Taina Litwak (Systematic Entomology Laboratory, ARS, USDA), who organized and mentored this and many other scientific illustration internships. Channing Richardson confirmed identification of the bryophytes.

Mention of trade names or commercial products in this publication is solely for the purpose of providing specific information and does not imply recommendation or endorsement by the USDA. The USDA is an equal opportunity provider and employer.

\section{References Cited}

Blake, D. H. 1943. The generic position of Hypolampsis pilosa (Illiger) and some related new species (Coleoptera: Halticidae). Proceedings of the Entomological Society of Washington 45(9): 207-221.

Casari, S. A., and C. N. Duckett. 1997. Description of immature stages of two species of Pseudolampsis 
(Coleoptera: Chrysomelidae) and the establishment of a new combination in the genus. Journal of New York Entomological Society 105(1-2): $50-64$.

Clark, S. M., D. G. LeDoux, T. N. Seeno, E. G. Riley, A. J. Gilbert, and J. M. Sullivan. 2004. Host Plants of Leaf Beetle Species occurring in the United States and Canada. The Coleopterists Society Special Publication No. 2. The Coleopterists Society, Sacramento, CA.

Cox, M. L. 1997. The larva of the flea beetle, Mniophila muscorum (Koch, 1803) (Coleoptera: Chrysomelidae, Alticinae), not a leaf-miner. Entomological Gazette 48: 275-283.

Damaška, A., and P. Aston. 2019. Leaf litter and mossinhabiting flea beetle of Hong Kong (Coleoptera: Chrysomelidae: Alticini). Acta Entomologica Musei Nationalis Pragae 59(1): 151-161.

Damaška, A., and A. S. Konstantinov. 2016. A new species of Cangshanaltica Konstantinov et al., a moss-inhabiting flea beetle from Thailand (Coleoptera: Chrysomelidae: Galerucinae: Alticini). Zootaxa 4107(1): 93-97.

Duckett, C. N. 2002. First description of larval stages of Walterianella bucki Bechyné (Coleoptera: Chrysomelidae: Alticini) and notes on life history. The Coleopterists Bulletin 56(2): 170-181.

Duckett, C. N., K. D. Prathapan, and A. S. Konstantinov. 2006. Notes on identity, new synonymy and larva of Ivalia Jacoby (Coleoptera, Chrysomelidae) with description of a new species. Zootaxa 1363: 49-68.

Duckett, C. N., and Z. Swigoňová. 2002. Description of immature stages of Alagoasa januaria Bechyné (Coleoptera: Chrysomelidae). Journal of New York Entomological Society 110(1): 115-126.

Folmer, O., M. Black, W. Hoeh, R. Lutz, and R. Vrijenhoek. 1994. DNA primers for amplification of mitochondrial cytochrome c oxidase subunit I from diverse metazoan invertebrates. Molecular Marine Biology and Biotechnology 3(5): 294-299.

Konstantinov, A. S. 1998. Revision of the Palearctic species of Aphthona Chevrolat and cladistic classification of the Aphthonini (Coleoptera: Chrysomelidae: Alticinae). Memoirs on Entomology, International. Associated Publishers, Gainesville, FL.

Konstantinov, A. S. 2016. Possible living fossil in Bolivia: A new genus of flea beetles with modified hind legs (Coleoptera, Chrysomelidae, Galerucinae, Alticini). ZooKeys 592: 103-120.

Konstantinov, A. S., A. Baselga, V. V. Grebennikov, J. Prena, and S. W. Lingafelter. 2011. Revision of the Palearctic Chaetocnema species (Coleoptera: Chrysomelidae: Galerucinae: Alticini). Pensoft Series Faunistica No 95, Pensoft Publishers, Sofia, Bulgaria.

Konstantinov, A. S., and M. L. Chamorro-Lacayo. 2006. A new genus of moss-inhabiting flea beetles (Coleoptera: Chrysomelidae) from the Dominican Republic. The Coleopterists Bulletin 60(4): 275-290.
Konstantinov, A. S., M. L. Chamorro, K. D. Prathapan, S.-Q. Ge, and X.-K. Yang. 2013. Moss-inhabiting flea beetles (Coleoptera: Chrysomelidae: Galerucinae: Alticini) with description of a new genus from Cangshan, China. Journal of Natural History 47(37-38): 2459-2477. DOI:10.1080/0022933.2012.763068

Konstantinov, A. S., M. L. Chamorro-Lacayo, and V. P. Savini. 2009. A new genus of moss-inhabiting flea beetles (Coleoptera: Chrysomelidae) from Nicaragua. The Coleopterists Bulletin 63(1): 1-12.

Konstantinov, A. S., A. M. Linzmeier, S. M. Clark, and M. A. Ivie. 2015. Review of the West Indian genus Monotalla Bechyné (Coleoptera, Chrysomelidae, Galerucinae, Alticini) with description of five new species. ZooKeys 505: 117-136.

Konstantinov, A. S., A. M. Linzmeier, and V. P. Savini. 2014. Stevenaltica, a new genus of moss and leaflitter inhabiting flea beetles from Bolivia (Coleoptera: Chrysomelidae: Galerucinae: Alticini). Proceedings of the Entomological Society of Washington 116(2): 159-171.

Lawrence, J. F., and A. Ślipiński. 2013. Australian beetles. Morphology, Classification and Keys. Volume 1. CSIRO Publishing, Collingwood, Australia.

LeSage, L., and A. Zmudzinska-Krzesinska. 2004. The immature stages of the grape flea beetles Altica chalybea Illiger and $A$. woodsi Isely (Coleoptera, Chrysomelidae) [pp. 503-528]. In: New Developments in the Biology of Chrysomelidae (P. Jolivet, J. A. Santiago-Blay, and M. Schmitt, editors). SPB Academic Publishing, the Netherlands.

Lingafelter, S. W., and A. S. Konstantinov. 2000. The monophyly and relative rank of alticine and galerucine leaf beetles: A cladistic analysis using adult morphological characters (Coleoptera: Chrysomelidae). Entomologica Scandinavica 30(4): 397 416.

McHugh, J. V., C. J. Marshall, and F. L. Fawcett. 1997. A study of adult morphology in Megalodacne heros (Say) (Coleoptera: Erotylidae). Transactions of the American Entomological Society 123(4): 167-223.

Nadein, K. S. 2009. Revision of the genus Mniophila Stephens, 1831 (Coleoptera: Chrysomelidae). Beitrage Entomologische. Keltern 59(1): 103-131.

Riley, E. G., S. M. Clark, and T. N. Seeno. 2003. Catalog of the Leaf Beetles of America North of Mexico (Coleoptera: Megalopodidae, Orsodacnidae and Chrysomelidae, excluding Bruchinae). The Coleopterists Society Special Publication No. 1. The Coleopterists Society, Sacramento, CA.

Takizawa, H., and A. S. Konstantinov. 2018. The genus Ivalia Jacoby 1887 (Coleoptera: Chrysomelidae: Galerucinae: Alticini) of the mount Kinabalu, Sabah, Malaysia. Journal of Insect Biodiversity 6(1): $1-23$.

(Received 4 March 2019; accepted 21 July 2019. Publication date 22 September 2019.) 